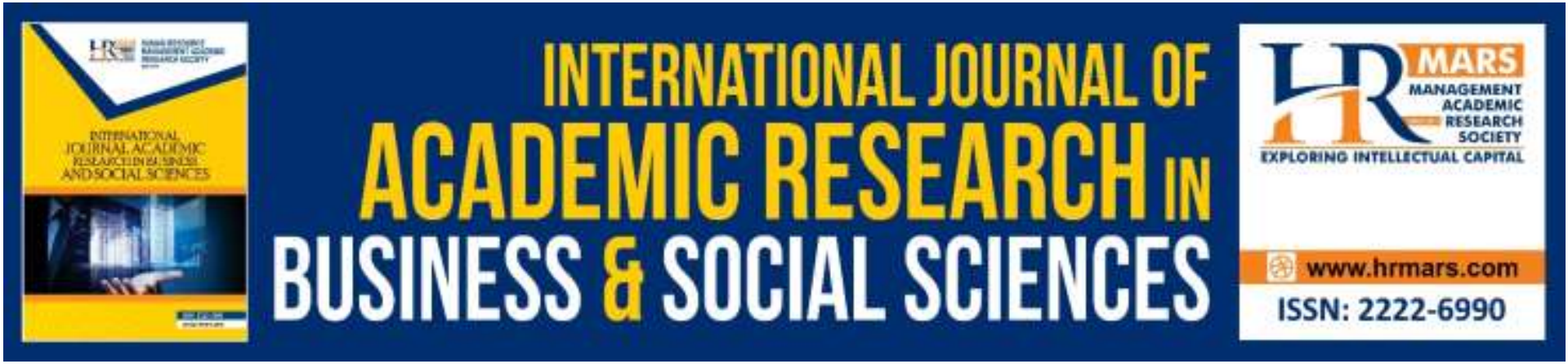

\title{
Work - Life Conflicts among Women in Malaysia: A Preliminary Study
}

Ahmad Fadhly Arham, Nor Sabrena Norizan, Abdul Rauf Ridzuan, Syarifah Nur Najiah Najela Syed Alwi, Ahmad Firdhaus Arham

To Link this Article: http://dx.doi.org/10.6007/IJARBSS/v9-i9/6337

DOI: $10.6007 /$ IJARBSS/v9-i9/6337

Received: 04 August 2019, Revised: 27 August 2019, Accepted: 04 September 2019

Published Online: 27 September 2019

In-Text Citation: (Arham, Norizan, Ridzuan, Alwi, \& Arham, 2019)

To Cite this Article: Arham, A. F., Norizan, N. S., Ridzuan, A. R., Alwi, S. N. N. N. S., \& Arham, A. F. (2019). Work Life Conflicts among Women in Malaysia: A Preliminary Study. International Journal of Academic Research in Business and Social Sciences, 9(9), 614-623.

\section{Copyright: (C) 2019 The Author(s)}

Published by Human Resource Management Academic Research Society (www.hrmars.com)

This article is published under the Creative Commons Attribution (CC BY 4.0) license. Anyone may reproduce, distribute, translate and create derivative works of this article (for both commercial and non-commercial purposes), subject to full attribution to the original publication and authors. The full terms of this license may be seen at: http://creativecommons.org/licences/by/4.0/legalcode

\section{Vol. 9, No. 9, 2019, Pg. 614 - 623}

Full Terms \& Conditions of access and use can be found at http://hrmars.com/index.php/pages/detail/publication-ethics 


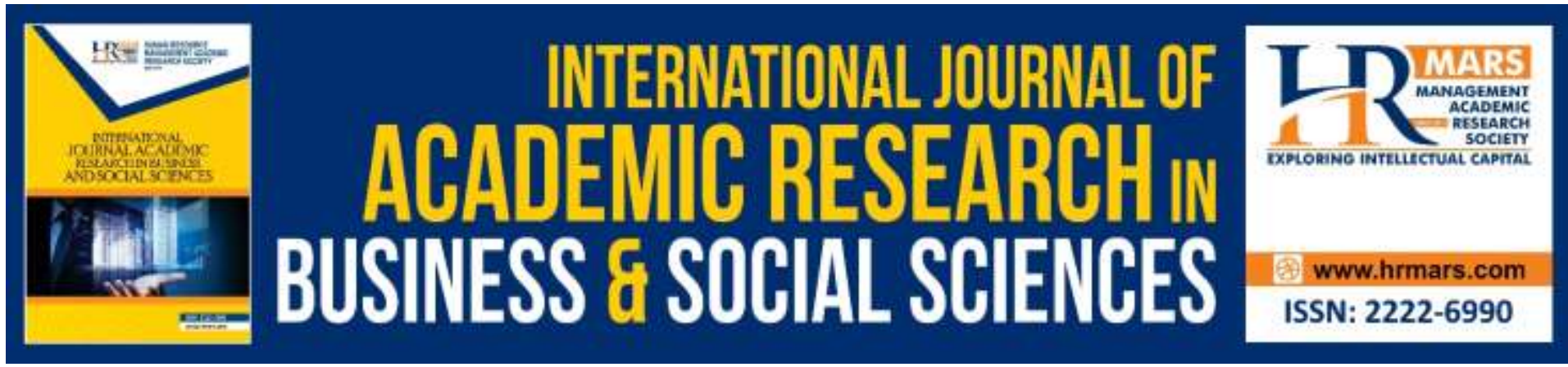

\title{
Work - Life Conflicts among Women in Malaysia: A Preliminary Study
}

\author{
${ }^{1}$ Ahmad Fadhly Arham, ${ }^{2}$ Nor Sabrena Norizan, ${ }^{3}$ Abdul Rauf \\ Ridzuan, ${ }^{4}$ Syarifah Nur Najiah Najela Syed Alwi, ${ }^{5}$ Ahmad \\ Firdhaus Arham \\ 1,2,3,4 Universiti Teknologi MARA, Melaka, Malaysia \\ ${ }^{5}$ Universiti Kebangsaan Malaysia
}

\begin{abstract}
Gender related studies are always engaging. Due to higher percentage of working women, many efforts are channeled to explore issues pertaining to women-at-work. Since many of these working women are also married and some with children, they seem to be dealing with more work-life conflict issues than men. Based on quantitative findings on 118 working women in the country, the following findings were drawn. Household responsibilities and financial needs have significant effect towards work-life conflicts. The rising costs of raising a family and having to deal and balance the responsibilities at work and at home seem to contribute to the work-life conflicts. However, the study failed to establish a significant relationship between workplace environment and work-life conflicts. It is hoped that the outcome of this study could shed some light on greater understanding about women at work. Keywords: Work-Life Conflicts, Women-At-Work, Household Responsibilities, Financial Needs, Workplace Environment
\end{abstract}

\section{Introduction}

Gender related studies are always engaging. In Malaysia, women make up almost half of the population, but they only represented $46 \%$ of the national labor force. This statistic is found to be amongst the lowest in Asian countries as compared to Singapore (60\%), Thailand (52\%) and Indonesia (52\%). Majority of women will enter the workforce upon graduation, but leave as soon as they started their family. Those who left, rarely will they return to work. Thus, the objective of this paper is to examine the factors affecting work-life conflicts among working women in Malaysia. To date, research in this area is still lacking and findings are inconclusive.

Adhikari (2012) contended that working mothers experiencing anxiety and stress symptoms mostly day by day. An increasing number of women are facing the tasks of juggling between mother-wife-employee roles. Working mother experienced high level of stress as compared with stayed home mothers. Due to high numbers of women at the workplace, the topic of work-life conflict has become a crucial topic for researchers. The work-life conflicts among 
employed women occur when they failed to manage and organize their life with families and work properly (Berger, 2018).

Working mothers tend to have more jobs and responsibilities in household chores than dads have. There are several duties such as children care, elderly care, house chores, and family needs that require mothers to sacrifice their time to bear with all of the responsibilities.

The general business problem was working mothers have a lack of time in order to carry two roles at a time. In fact, research indicates that working mothers will face conflicts when they try to balance between family and demands (Berger, 2018). Thus, women underwent severe stress in the process of attaining Work-life Balance and continued work pressure can result in poor performance (Sudha \& Karthikeyan, 2014). This means that women are facing conflicts to make their life balance between work and families. Data showed that career-oriented women have to manage and balance work and life due to stereotypic roles played. There is highly much significant relationship between work-life balance and work-life conflict. Even for women who received support from family members are still often underwent conflict on not managing both sides effectively. Also, study shown that most of women are working 40-45 hours per week out of which almost 53 percent of them are struggling to get work-life balance. The challenge and demands from their organization versus the commitment of their home is the reason behind all of it (Padmanabhan \& Kumar, 2016).

Thus, the objective of this paper is to examine the relationship between household responsibilities, financial need and workplace environment towards work-life conflict. It is hoped that the outcome of this study could shed some light on greater understanding about women at work.

\section{Literature Review \\ Overview of Women at Workforce}

In year of 1995, the proportion of percentage has slashed from 2.8 to 2.6 percent in year 1996. Since 1970, women participation has increased a great deal within the labor. Even if Malaya could be a fresh industrializing country, the feminine labor participation rate compares favorably with industrialized countries of the Asia and Pacific region. Women additionally represent 43.4 percent of hands within the producing sector (Ahmad, 1998).

According to Corp (2016), Malaysia has made a major progress in the past six years in increasing the number of women in the workforce and in decision-making role in the corporate sector on the back of several Government initiatives rolled out to enhance the contribution of women to Malaysia's economy and promote greater inclusiveness in the workforce. This can be supported by Khan (2017), statistically, 54\% of Malaysian women are earning their own money and according to the data released by UOB Malaysia, women are increasingly using their Mastercard to pay for basic necessities such as insurance, groceries and utilities; as well as necessities like travel, lifestyle and shopping.

\section{Work - Life Conflict}

Women have gotten into jobs and that they still work even once marriage. A married person has a lot of responsibility than man in taking care of young kids and family. The working 
women with efficiency overcome tough situations by their commitment and perseverance. The participation of women in financial gain generation activities lends them to satisfy their home needs to a greater extent (Julka \& Mathur, 2017).

In the past twenty-five years, there has been a substantial increase in work because of info technology, intense work surroundings and a performance culture in most of the organizations expects more and more from their staff however offers very little security reciprocally (Mukarram, Akbar, Jan, \& Gul, 2012). Conflict is created because of certain reasons. For instance, once strain created because of performing one role makes it tough for the person to perform another role at that point and additionally when specific behaviors are allocated to only one role while one must perform two roles (Mukarram, Akbar, Jan, \& Gul, 2012).

According to Sundaresan, (2014) when a woman search a position of power within an organization, she must consider the toll on other facets of her life, including hobbies, personal relationships and family. Most executive jobs require a substantial amount of time and effort, which a working mother may not be able to devote due to family obligations. Also, it may be nearly impossible for a working mother in a top management position to be the primary care giver of her child. Women often find it more difficult to maintain balance on account of the competing pressures of work and demands at home. Working women need to fastidiously handle their personal balance and elegantly mix their roles, thus on optimize their potential altogether quadrants of life.

\section{Household Responsibilities}

According to Yapp (2018), women still need to do the lion's share of housework despite going out to work in ever increasing digits. He found that they spent three times longer on domestic chores, such as cooking, cleaning and washing, as their husbands or partners.

In the US, women are also faced with the same issues as in Malaysia. According to Stalsburg (2017), while women and men could have achieved parity when it involves monetary obligations, with different tasks, women shouldered much more responsibility than men. Women are way more likely than men to be responsible for buying groceries, preparation and preparing meals, household cleaning, and planning social activities.

\section{Workplace Environment}

One of the important factors affecting employees' well-being, capabilities, performance and health within the work is workplace environment. In Bangkok, the survey found that women who had issues within the working atmosphere represented a total of 86,565 women workers $(54,739$ workers in the formal sector and 31,826 workers in the informal sector), representing 4.70 percent of women workers with problems related to the working environment of the country. Out of the eight categories described above, the most important issue was the dust, smoke, odor, representing 44.69 percent, followed by the working conditions, representing 35.32 percent. Problems such as a restricted and dirty working area, bad ventilation, noise, inadequate lighting and others, only ranged from 0.71 percent to 5 percent (Pipitkul, et al., 2015). 
However, there is an even bigger issue that affects women within the working environment. Sexual harassment at work is one of the most widespread issues that most women employees are facing. Sexual harassment is an unwelcome sexual behavior, be it verbal or physical, and has profound impact on women.

\section{Financial Need}

According to Basu (2016), financial planning is the method of meeting your life goals through the right management of your finances. Life goals can include buying a house, saving for your child's higher education or planning for retirement. According to Emam (2017), at a panel held by the Young Entrepreneurs Association (YEA), they agreed that the present economic scenario should act as a catalyst for women's work participation in order to spice up economic growth.

In general, women have an extended expectancy, as compared with men. For instance, women live on average, six years longer than men, thus there is a higher risk of them outliving their spouses. This can be supported with Desjardins (2018), which states that men dying sooner than women make sense biologically because 105 males are born for every 100 females, it would assure that there are about a similar number of men and women at reproductive ages. But even though women showed a longer life expectancy in almost every human society in the last decade of the 20th century, the size of the advantage varied greatly. For example, in the U.S. male life expectancy was 73.4 years for males and 80.1 years for females, a difference of 6.7 years, whereas in France it was 7.8 years and, in the U.K., 5.3 years. Because of their life expectancy is longer, they are facing with more financial challenges in the future and they need to save more. 


\section{Research Framework}

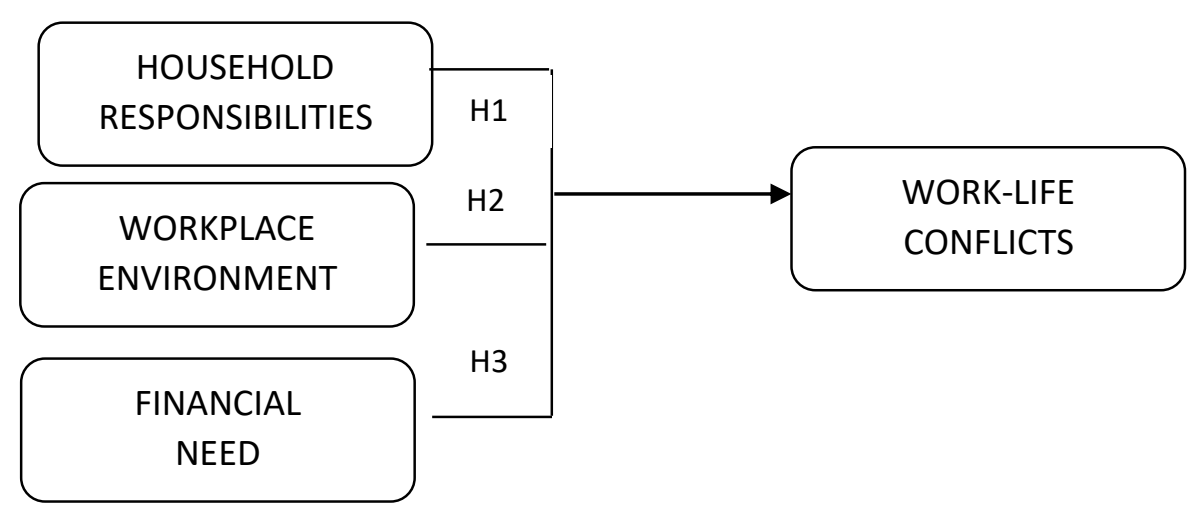

Figure 1: Theoretical Framework

Source: (Ahmad, Fkhr, Ahmed, 2011)

\section{Research Methodology}

This study adopts a quantitative approach. It is a preliminary gathering of feedback among respondents on the issue of work-life conflicts. The data were targeted and collected among the working women in the central and southern regions of the country. This study managed to obtained 118 completed and returned questionnaires out of 120 distributed. Due to its preliminary in nature and considering that the framework adopted for this study fit in into a model containing five or fewer constructs, Hair et al. (2010) suggested to have a minimum of 100 as a sample size. Due to the preliminary nature of this study, the sampling technique used was convenience sampling. Thus, only women who are working at the time the data was collected are considered as sample of this study.

The research instruments for this study were the questionnaires relate to the research objectives, in order to identify the conflicts that women faced while working. The instruments were adopted from Ahmad, Fkhr, \& Ahmed (2011). There are five parts in this questionnaire. Part $A$ consists of questions relating to the demographic variables of respondents. Part $B$ of the questionnaire consists of questions relating to the work-life conflicts. Part $C$ of the questionnaire consists of questions relating to the household responsibilities. Part $D$ of the questionnaire consists of questions relating to the financial need. Part $E$ of the questionnaire consists of questions relating to the workplace environment. All questions in Part $B$ to $D$ are using five-point Likert-scales which ranging from 1 - strongly disagree to 5 strongly agree.

\section{Findings and Analysis \\ Reliability}

The Cronbach's alpha for all variables ranging from 0.743 to 0.893 . The reliability of measurements used to measure dependent and independent variables are very good. Thus, it can be concluded that measurement items are deemed to be acceptable and reliable for this study. 


\section{Demographic of Respondents}

Based from the analysis, $96.6 \%$ of the respondents are married, and $3.4 \%$ of the respondents are divorced. The highest age group is between $31-40$ years old which contributed $54.2 \%$ of the total respondents. The lowest age group contributed $11.9 \%$ representing those aged more than 50 years old. Meanwhile, age group between $21-30$ and $41-50$ years old contributed $16.9 \%$ each.

Majority are married with less than three kids representing $40.7 \%$. Degree and diploma holders contributed $33.9 \% 32.2 \%$ respectively of total respondents.

Most of the respondents work more than 10 years with $40.7 \%$. Second, $25.4 \%$ of the respondents have been working for $4-7$ years. 23.7\%, the respondents have work for less than three years and lastly, with only $10.2 \%$ of the respondents they have work for $8-10$ years.

Among all of the married respondents, the longest they have been together is more than 10 years with $44.1 \%$. $30.5 \%$ of them have been together for $4-7$ years. $18.6 \%$ of them have been for only $1-3$ years and the last one represented by $6.8 \%$ is those who have been together for $8-10$ years. Most of the respondents work in private sector with $66.1 \%, 30.5 \%$ of them work with government and $3.4 \%$ of them are self-employed.

\section{Correlation}

Table 1: Summary on Pearson Correlations Coefficient

\begin{tabular}{|c|c|c|c|}
\hline & $\begin{array}{c}\text { Household } \\
\text { Responsibilities }\end{array}$ & $\begin{array}{c}\text { Financial } \\
\text { Need }\end{array}$ & $\begin{array}{c}\text { Workplace } \\
\text { Environment }\end{array}$ \\
\hline Work-life & $0.490^{* *}$ & $0.330^{* *}$ & -0.045 \\
Conflicts & .000 & .000 & 0.628 \\
\hline \multicolumn{2}{|r|}{$*$ Correlation is significant at the 0.01 level (2-tailed). } \\
\hline
\end{tabular}

The above table explained the results from the correlation analysis. Based from the table, it is found that there is a positive and significant relationship between household responsibilities and work-life conflict $(r=0.490 ; p<0.05)$. This indicates that those two variables have a significant and moderate relationship. The correlation between financial need and work-life conflicts also shows a positive and significant relationship $(r=0.330 ; p$ $<0.05)$. This indicates that those two variables have a significant and weak relationship. The correlation coefficient between workplace environment and work-life conflict is found to be insignificant $(r=-0.045 ; p>0.05)$. 


\section{Multiple Regression Analysis}

Table 2: Summary of Multiple Regression Analysis

\begin{tabular}{|c|c|c|}
\hline \multicolumn{3}{|c|}{ Dependent Variable: Work-life Conflict } \\
\hline \multirow{4}{*}{ Model } & Independent Variable & Standard Coefficient, $\beta$ \\
\hline & Household Responsibilities & $.436(p<0.01)$ \\
\cline { 2 - 3 } & Financial Need & $.194(p<0.01)$ \\
\cline { 2 - 3 } & Workplace Environment & $-.075(p>0.05)$ \\
\hline F & \multicolumn{2}{|c|}{14.829} \\
\hline R Squared & \multicolumn{2}{|c|}{281} \\
\hline
\end{tabular}

The results reported in the above table show that the model of this study is significant ( $\mathrm{F}$ : $14.829, p<0.01)$. The $R$ Squared value indicates that the percentage effect by combining all independent variables is $28.1 \%$. This shows $28.1 \%$ variability in dependent variable (Work-life Conflict) was influenced by independent variables (Household Responsibilities, Financial Need, Workplace Environment) and $71.9 \%$ were influenced by other factors.

Of the three independent variables, only two have a significant unique contribution to Worklife conflict. These variables are Household Responsibilities $(\beta: .436, p<0.01)$ and Financial Need $(\beta$ : .194, $p<0.01)$. Thus, $\mathrm{H} 1$ and $\mathrm{H} 2$ are supported. Workplace Environment, $(\beta:-.075$, $p>0.01$ ) did not have a significant effect. Thus, H3 is not supported.

\section{Discussion and Conclusion}

Overall, the analyses conducted in this study were able to find answers to the main objective of this study. Preliminarily, the combination of independent variables of this study can cause approximately almost $30 \%$ variation in the dependent variable. Besides, household responsibility and financial need were found to have a significant relationship and effect towards work-life conflicts. However, the data failed to find any support for the relationship between workplace environment and work-life conflict.

This study concludes that household responsibilities correlate and affect work-life conflict among working women. Omara, Ahmad, \& Ismail, (2016) also contended that household responsibilities affect work-life conflicts among working women. It shows that household responsibilities do influence work-life conflicts. Since majority of respondents in this preliminary study were married with at least three kids. Thus, having to manage the family chores and the kids at home is seemed to possibly contribute to their work-life conflicts. However, the more experience that they are having at their workplace may help them to better manage their time. Also, support and teamwork from the spouse is very important.

This study also concludes that financial need correlates and affects work-life conflicts. Also, Omara, Ahmad, \& Ismail (2016) found that employees' financial needs would relate with their work-life conflict. The result exhibited that financial needs and work-life conflict were significantly associated with a positive relationship. The increase in the family spending perhaps influence these women to work in order to help the family financially. 
However, this study failed to find support between workplace environment and work-life conflict. Perhaps, majority of respondents in this study have had good enough experience at their work with majority of respondents, approximately more than $50 \%$ of total respondents have had more than 8 years or working experience. Thus, they are able to absorb the pressure at the workplace environment so that they will not interfere with their work-life conflicts. From another perspective, due to their understanding that workplace and "matters-at-home" are both equally important, they know how critical they need to balance between both issues. Perhaps, they will depend more on the spouse to look after "matters-at-home" at times when they are more critical issues to be handled at work.

Thus, this study suggests that having support and understanding from the spouse and family members is one of the critical factors towards stability at the workplace among these working women. Perhaps, when they have full support from family members, things at work would become more manageable to them.

The outcomes of this study present managerial and theoretical implications First, governing body relating to women in the country should consider to revise the pay-scale for women at work in Malaysia. The pay-scale for women should be the same as their counterparts in the country, as the reason for many of them to be employed is as financially important as any man. The governing body also might want to consider providing financial assistance in the form of incentives especially for those women with two or more children who are working. Second, the outcomes also indicated that, theoretically, factors inluencing work-life conflicts are household responsibilities and financial needs.

This study is not without limitations. First, this study used a convenience sampling. Perhaps, to have results that truly representative of Malaysian population, this study suggests future research to employ a probability sampling. Second, this study used a cross-sectional data.

Perhaps a longitudinal data might enhance the outcome of this research.

\section{References}

Adhikari, D. (2012). Anxiety and Depression: Comparative Study between working and NonWorking mothers. Global Journal of Human Social Science Sociology, Economics \& Political Science, 12 (12), 1-7.

Ahmad, A. (1998, December). Women in Malaysia: Country Briefing Paper. Retrieved from https://www.adb.org/sites/default/files/institutional-document/32552/womenmalaysia.pdf

Ahmad, M. S., Fkhr, Z., \& Ahmed, J. (2011). Working Women work life conflict. Emerald Insight, 12 (6), 289-302.

Basu, R. M. (2016). Investments and Directory for Financial Advisors. Retrieved from https://www.advisorkhoj.com/principalmf/Why-do-Women-need-Financial-Planning

Berger, L. (2018). Working mothers work and family satisfaction: The influence of time demands and time-based conflict. Journal of Mental Disorder and Treatment, 2018, Vol 4(2): 1-8.

Corp, T. (2016, June 27). GOVERNMENT'S INITIATIVES TO INCREASE WOMEN IN THE WORKFORCE MAKE HEADWAY. Retrieved from 
https://www.talentcorp.com.my/resources/press-releases/governments-initiatives-toincrease-women-in-the-workforce-make-headway

Desjardins, B. (2004). Why is life expectancy longer for women than it is for men? Retrieved from

https://www.scientificamerican.com/article/why-is-life-expectancy-lo/.

Emam, D. A. (2017). Women's increasing workplace participation mainly due to financial need - economist. Retrieved from The Jordan Times.

Hair, J.F., Black, W.C., Babin, B. J., Anderson, R. E., (2010). Multivariate Data Analysis, $7^{\text {th }}$ ed., Pearson.

Julka, T., \& Mathur, U. (2017). A Conceptual Study of Work- Life Balance among Women employees. International Journal of Emerging Research in Management \& Technology , 6 (2), 74-78.

Khan, N. (2017, 107). Women in Malaysia more empowered today. Retrieved from The Star Online: https://www.thestar.com.my/business/business-news/2017/10/07/womenin-malaysia-more-empowered-today/

Mukarram, A, Akbar, S., Jan, Z., \& Gul, A. (2012). Work life conflict impact on Female's Job performance. A study of primary level female school teachers in Pakistan. European Journal of Business and Management, 4 (20), 74-84.

Omara, M. K., Ahmad, M. F., \& Ismail, I. S. (2016). Personal factor and work life conflicts-A study of Malaysian Statutory Body. The European Proceedings of social and behavioral sciences, 3rd International Conference on Business and Economics, 21 - 23 September, 2016 251-261.

Padmanabhan, M., \& Kumar, S. S. (2016). Work life balance and work life conflict on career advancement of women professionals in information and communication technology sector. International Journal of Research Granthaalayah, 4 (6), 119-130

Pipitkul, S., Amnajsathit, S., Lakhumlek, W., Saleerat, P., Laohasinnuruk, R., Nimitcharoen, S., et al. (2015). The working environment of women workers in Bangkok. Retrieved from wiki gender: https://www.wikigender.org/wiki/the-working-environment-of-womenworkers-in-bangkok/

Stalsburg, B. L. (2017, 12 6). Women Are Working More Than Ever-Inside The Home And OutWomen Are Working More Than Ever-Inside The Home And Out. Retrieved from https://www.huffingtonpost.com/brittany-I-stalsburg-phd/women-are-working-moreth_b_9878996.html

Sudha, J., \& Karthikeyan, D. P. (2014). Work Life Balance of Women Employee: A Literature Review. International Journal of Management Research and Review, 4 (8), 797-804 .

Sundaresan, S. (2014). WORK-LIFE BALANCE - IMPLICATIONS FOR WORKING WOMEN. OIDAInternational Journal of Sustainable Development, 7 (7), 93-102.

Yapp, R. (2018). Working Women still do house work. Retrieved from Daily Mail http://www.dailymail.co.uk/news/article-206381/Working-women-housework.html 